Received 05.08.2015 Reviewed 04.12 .2015 Accepted 05.01.2016

A - study design

B - data collection

C - statistical analysis

D - data interpretation

E - manuscript preparation

F - literature search

\section{Estimation of parametric flood hydrograph determined by means of Strupczewski method in the Vistula and Odra catchments}

\author{
Wiesław GĄDEK ${ }^{1) \text { ABCDEF }}$, Tamara TOKARCZYK ${ }^{2) ~ A B C D E F, ~}$ \\ Arkadiusz ŚRODULA ${ }^{3) \text { BCD }}$
}

\footnotetext{
${ }^{1)}$ Cracow University of Technology, Institute of Water Engineering and Water Management, ul. Warszawska 24, 31-155 Kraków, Poland; tel. +48 12-628-28-54; e-mail: wieslaw.gadek@iigw.pk.edu.pl

${ }^{2)}$ Institute of Meteorology and Water Management - National Research Institute, Flood and Drought Modeling Centre, Wrocław, Poland; e-mail: tamara.tokarczyk@imgw.pl

3) Arcadis Ltd., Kraków, Poland; e-mail: arkadiusz.srodula@arcadis.com
}

For citation: Gądek W., Tokarczyk T., Środula A. 2016. Estimation of parametric flood hydrograph determined by means of Strupczewski method in the Vistula and Odra catchments. Journal of Water and Land Development. No. 31 p. 43-51. DOI: 10.1515/jwld-2016-0035.

\begin{abstract}
While determining theoretical flood hydrographs, different methods of their construction are used depending on the needs of the problem or the scope of the project. It should be remembered that these methods differ mainly with the principle of the waveform averaging, which may be done either according to the flow or time. The hydrographs may be divided into nonparametric (determining on the basis of registered floods) and parametric (using mathematical description of the flood course). One of the analytical methods is Strupczewski method which has two parameters: responsible for the waveform and specifies the base flow, the flow above which values of hydrograph are calculated. The functional description uses the Pearson type III density distribution.

The estimation of parametric flood hydrographs determined by means of Strupczewski method was carried out in the case when a nonparametric flood hydrograph suggested by the author was replaced with a nonparametric flood hydrograph computed using so called Cracow method. There was also made an estimation of flood hydrographs computed for single real hydrographs with the highest registered discharge and for so called typical hydrographs considering the volume.

Comparative analyses were carried out for 20 gauging stations in the upper Vistula and in the middle Odra rivers catchments. The analysis revealed that hypothetical hydrographs determined using the Cracow method may be used in Strupczewski method as a nonparametric input hydrograph. Also real hydrographs meeting the criterion of a typical hydrograph due to their volume, may provide a basis for determination of a parametric flood.
\end{abstract}

Key words: analytical flood hydrograph, nonparametric hydrograph, parametric hydrograph, Strupczewski method, the Cracow method, typical hydrograph

\section{INTRODUCTION}

Usually the term design flood hydrograph is treated in the same way as parametric flood hydrograph. These terms should be distinguished, considering the methods of determination and the way of pres- entation of the flow hydrographs. The authors of this paper understand the term design flood hydrograph as a flow hydrograph presenting a typical, under specific conditions, flood hydrograph course, for a determined place, which is used for design purposes. On the other hand, a parametric (or analytical) flood hydrograph is 
understood as an equation or a set of equations describing a nonparametric flood hydrograph. Such approach represents a major difference, since the design flood hydrograph is represented as a flow hydrograph, whereas a parametric flood hydrograph by means of a function with estimated parameters, of which the discharge values are computed from the assigned rising or duration time. The methods of nonparametric flood hydrographs determination comprise: the Cracow Technical University method, the Hydroproject method [GACDEK, ŚRODULA 2014], the Cracow method [GADEK, TOKARCZYK 2015], and the method using averaging by time [ARCHER et al. 2000], whereas the methods used for parametric floods determination were developed by: STRUPCZEWSKI [1964], MCENROE [1992], BAPTIST and MiCHEL [1990], and the parabolic functions: using Gama, Inverse Gaussian distribution, Negative Binomial curve [O'CONNOR et al. 2014], Weibull distribution and Hayashi curve [HAYASHI et al. 1986].

Both nonparametric and parametric flood hydrographs are determined mainly to assess the flood risk. They are also applied for designing the retention reservoirs capacity, which are used among others to alleviate the drought results [MIODUSZEWSKI 2012; 2014]. However, the literature of the subject lacks descriptions of the applications of similar solutions for the needs of drought risk estimation, although the results might be similar [TOKARCZYK, SZALIŃSKA 2013].

Most frequently parametric and nonparametric flood hydrographs are used for solving problems associated with a widely understood flood risk [APEL et al. 2006; CRISS, WINSTON 2008; HATTERMANN, KUNDZEWICZ (ed.) 2010; KRIŠČIUKAITIENĖ et al. 2015; VRIJLING et al. 1998]. The data describing the course of the flood hydrograph, its volume, rising time and duration provide a basis for delineation of flood risk zones, determining the time of water residing in the inter-embankment zone, computing the volume of water overflowing embankment crown or the volume of water outflowing in result of embankment break, as well as for solving a number of issues in the field of water construction and water management. The knowledge of wave transformation in the river bed is crucial for designing objects in urbanized catchments, where both rainwater and combined sewer systems, as well as the level of surface sealing play a key role in flood risk estimation [WMO 2008; ZEVENBERGEN et al. 2011]. Frequently, these hydrographs are used for an estimation of flood risk for urbanized areas for which a changed management is planned.

Attempts of hydrological models application are made in the ungauged catchments to determine theoretical floods [PIETRUSIEWICZ et al. 2014; WAŁĘGA 2013]. Flow hydrographs were generated in the hydrological modelling process for the assigned rainfall events. In this approach it is often assumed that the probability of 24-hour rainfall is the same as the probability of a runoff from the modeled catchment. It is an assumption, which not always corresponds with real flood formation, as has been proved by the computational simulations [GĄDEK, BODZIONY 2015]. The other problems are determining the distribution of rainfall over time (hyetograph) with assigned exceedance probability [WYPYCH et al. 2014] and determination of the maximum catchment area for which these solutions may be applied. Many researchers see the solution in the application of integral hydrological models with parameters distributed for large catchments [DOWNER et al. 2000; OZGA-ZIELIŃSKA et al. 2002]. Exponential replacement recessions are also used, which need developing of thematic layers for Geographic Information System (GIS) for unanimous determination of the catchment parameters. The same problem concerns also hydrological modeling.

The aim of presented paper is conducting an estimation of type I parametric flood hydrograph equation basing on Pearson type II density distribution developed by Strupczewski for applied nonparametric flood hydrograph determined by means of the Cracow method. The paper aims also at an estimation of potential application to this equation of single unimodal hydrographs with the highest documented discharge value and for so called "typical hydrograph" due to its volume. The estimation was conducted on the basis of comparison of the computed volumes (parametric flood hydrograph) with the volumes of the input (nonparametric) flood hydrographs for two basins of the Upper Vistula and Middle Odra rivers. 10 gauging stations were selected from each basin, characterized by a different geographical location and closing the catchments of different areas.

\section{SYNTHETIC DESCRIPTION OF STRUPCZEWSKI METHOD}

Strupczewski method is used for determining a parametric flood hydrograph [STRUPCZEWSKI 1964; CIEPIELOWSKI 1987; 2001]. The method was developed in two independent versions. The first solution refers to normal hydrographs, most frequently occurring in catchments, the second to hydrographs with slower recession limb in relation to normal hydrographs. Both equations use Pearson density distributions, however, type III was used for the first equation and type IV for the second. The first equation has the following shape:

$$
Q_{t}=Q_{\max p \%}\left\{a\left(\frac{t}{t_{w}}\right)^{n} \exp \frac{m}{n}\left[1-\left(\frac{t}{t_{w}}\right)^{n}\right]+b\right\}
$$

where: $Q_{t}=$ flow in a moment of time $t$ counted from the start of the flood $\mathrm{m}^{3} \cdot \mathrm{s}^{-1} ; Q_{\max p \%}=$ maximum flow with determined probability of exceedance $p \%, \mathrm{~m}^{3} \cdot \mathrm{s}^{-1}$; $t_{w}=$ time of rising, $\mathrm{h} ; t=$ time counted from the assumed start of flood, h; $m, n=$ parameters of flood shape; $a, b=$ equation parameters.

The equation parameters are established on the basis of averaged dimensionless flood hydrograph, 
where parameter $b$ denotes the value of initial flood flow, whereas parameter $a$ is supplementation to one $a=1-b$.

The other two parameters connected with the flood hydrograph shape are set on the basis of the following functions:

$$
\begin{gathered}
f_{0}(m, n)=\frac{n^{\frac{m+1}{n}-1}}{m^{\frac{m+1}{n}}} e^{\frac{m}{n}} \Gamma\left(\frac{m+1}{n}\right) \\
f_{1}(m, n)=\left(\frac{n}{m}\right)^{\frac{1}{n}} \frac{\Gamma\left(\frac{m+2}{n}\right)}{\Gamma\left(\frac{m+1}{n}\right)}
\end{gathered}
$$

Nonparametric flood hydrograph in Strupczewski method is determined on the basis of average dimensionless flood hydrograph using a minimum of six flow hydrographs with maximum flows registered in a given gauging cross section. Dimensionless values of flow $q$ from 0 to 1 are determined for strictly assigned value of dimensionless time from 0 to 1 for the rising limb and from 1 to 5 for the receding limb.

The second equation with the Pearson type IV density distribution is meant for the areas where the duration time of flood recession phase is at least seven-fold longer than the time of rising.

\section{SYNTHETIC DESCRIPTION OF THE CRACOW METHOD}

The Cracow method was developed at the Institute of Water Engineering and Water Management of the Cracow University of Technology. The nonparametric hydrograph is determined using a normalized unit hydrograph developed on the basis of at least 8 biggest registered floods. The dimensionless form of the hydrograph assumes the value of flow within the 0 to 1 a range the duration time from 0 to 1 for the rise phase and from 1 to 2 for the recession phase. The rise time and recession time are standardized independently, however the value of maximum flow is reduced by value of flow $Q_{50 \%}$. In this method, additionally two linear relationships are set, which determine the dependence of flood duration time on the time of rise and reduced volume (computed for the flows above $Q_{50 \%}$ ) on the reduced maximum flow (flows reduced by $Q_{50 \%}$ ) [GĄDEK, TOKARCZYK 2015].

\section{CHARACTERISTICS OF SELECTED CATCHMENTS}

The analysis of results was conducted on the basis of flow hydrographs observed in 20 gauging stations situated in the area of the upper Vistula and middle Odra catchments. The selected catchments represent areas with different landforms. The selection was made in order that the catchments would represent mountain and sub-mountain, as well as upland and lowland areas. Their short characteristics was presented in Table 1, where the catchments were
Table 1. Short characteristics of the catchments selected for

\begin{tabular}{|c|c|c|c|}
\hline No. & River - gauging station & $\begin{array}{c}\text { Catchment area } \\
\mathrm{km}^{2}\end{array}$ & $I Q_{p \%}$ \\
\hline \multicolumn{4}{|c|}{ The Odra basin } \\
\hline 1 & Nysa Kłodzka - Międzylesie & 49,7 & 9,4 \\
\hline 2 & Bystrzyca - Bystrzyca Kłodzka & 64 & 4,4 \\
\hline 3 & Ścinawka - Tłumaczów & 256 & 5,6 \\
\hline 4 & Strzegomka - Łażany & 362,3 & 7,3 \\
\hline 5 & Bóbr - Wojanów & 535,2 & 4,2 \\
\hline 6 & Bóbr - Jelenia Góra & 1047 & 5,0 \\
\hline 7 & Nysa Kłodzka - Kłodzko & 1084 & 5,4 \\
\hline 8 & Nysa Kłodzka - Bardo & 1744 & 4,9 \\
\hline 9 & Bóbr - Szprotawa & 2879 & 7,0 \\
\hline 10 & Odra-Głogów & 36403 & 3,2 \\
\hline \multicolumn{4}{|c|}{ The Vistula basin } \\
\hline 11 & Lubieńka-Lubień & 46,9 & 5,6 \\
\hline 12 & Bystra - Kamesznica & 48,2 & 5,0 \\
\hline 13 & Koprzywianka - Koprzywnica & 498 & 3,4 \\
\hline 14 & Przemsza - Jeleń & 2006 & 2,1 \\
\hline 15 & Poprad - Stary Sącz & 2071 & 4,1 \\
\hline 16 & Nida - Brzegi & 3359 & 4,5 \\
\hline 17 & San - Przemyśl & 3686 & 3,4 \\
\hline 18 & Wisłoka-Mielec & 3893 & 3,1 \\
\hline 19 & Dunajec - Żabno & 6735 & 5,2 \\
\hline 20 & Wisła-Zawichost & 50732 & 3,4 \\
\hline
\end{tabular}
the comparative calculations

Source: own study.

systematized by their affiliation to a river basin (the Odra basin - 1 to 10 , and the Vistula basin 11 to 20) and according to their area.

The flow quotient $I Q_{p \%}$ determines the dynamics of flood flows:

$$
I Q_{p \%}=\frac{Q_{1 \%}}{Q_{50 \%}}
$$

where: $I Q_{p \%}=$ the quotient of annual maximum flows with assigned exceedance probability determining the dynamics of flow changes; $Q_{1 \%}, Q_{50 \%}=$ the maximum annual flow with assigned exceedance probability $p=$ $1 \%$ and $p=50 \%, \mathrm{~m}^{3} \cdot \mathrm{s}^{-1}$.

\section{METHODS}

The analyses were conducted for two cases. In the first, tested was the possibility of application in Strupczewski method of nonparametric flood hydrographs obtained by means of the Cracow method instead of the method suggested by the author. In the authors' opinion, application of the Cracow method seems right, because this method includes the following dependencies: (i) the duration time of flood from the time of rising and (ii) reduced volume of the flood from the reduced maximum flow. The other methods of this type lack similar solutions. In the second variant, it was tested if it were possible to directly set the parameters of function for single floods. In this case the choice of flood would be based on the criterion of the highest maximum registered discharge or flood representing so called "typical hydrograph" because 
of its volume. The term "typical hydrograph" is difficult to define unanimously. It is due to the uniqueness of each real flood regarding the maximum flow, duration time and course. Partly the problem may be solved by the application of standardization to obtain a unified hydrograph in which the maximum flow assumes value 1 , whereas the other values are determined from the dependence:

$$
q_{i}=\frac{Q_{i}}{Q_{\max }}
$$

where: $q_{i}=$ unit flow at the $i$-th time step; $Q_{i}=$ flow at the $i$-th time step, $\mathrm{m}^{3} \cdot \mathrm{s}^{-1} ; Q_{\max }=\operatorname{maximum}$ flood flow, $\mathrm{m}^{3} \cdot \mathrm{s}^{-1}$.

Hydrograph unification procedures were used in order to calculate the parameters of the hydrograph shape $m$ and $n$ for single flood, according to the principle, that the rising time is counted from 0 to 1 , while the recession time from 1 to maximum 5 . The conducted estimation assumed, that floods would be compared in the flow area over $Q_{50 \%}$. Standardized hydrographs were converted into flow hydrographs in which the maximum value was $Q_{1 \%}$ and the rise time was assumed as for the nonparametric flood hydrograph.

The estimation measure was relative deviation of the reduced volume of parametric flood computed using Strupczewski method in regard to reduced volume for nonparametric flood hydrograph which was the input for Strupczewski method. Computations of volumes were conducted for individual floods for the rising limb of the flood hydrograph and for the whole hydrograph:

$$
E r V=\frac{V_{p}-V_{n}}{V_{n}} 100 \%
$$

where: $E r V=$ relative deviation of reduced volume of theoretical flood hydrograph computed using Strupczewski method, $\% ; V_{p}=$ reduced volume of parametric flood, $10^{6} \mathrm{~m}^{3} ; V_{n}=$ reduced volume of nonparametric flood, $10^{6} \mathrm{~m}^{3}$.

Additionally mean deviation was calculated for the value of flow computed with reference to the hydrograph of nonparametric flood flow, in relation to the maximum flow $Q_{1 \%}$ :

$$
\operatorname{ErQ}=\frac{\frac{\sum_{i=1}^{n}\left|Q_{i s}-Q_{i w e}\right|}{n}}{Q_{1 \%}} 100 \%
$$

where: $\operatorname{Er} Q=$ mean deviation of the value of flow hydrograph computed from Strupczewski formula in regard to the maximum flow of theoretical flood, \%; $Q_{1 \%}=$ maximum flow with assigned exceedance probability $\mathrm{p}=1 \%, \mathrm{~m}^{3} \cdot \mathrm{s}^{-1} ; Q_{i s}-$ flow in a moment of time $i$ computed from Strupczewski equation, $\mathrm{m}^{3} \cdot \mathrm{s}^{-1}$; $Q_{\text {iwe }}=$ flow in a moment of time of the input hydrograph, $\mathrm{m}^{3} \cdot \mathrm{s}^{-1} ; n=$ number of time steps of standard flow hydrograph duration.
In order to develop a "typical hydrograph" using the suggested method, four biggest unimodal floods were identified, for which the dependence was established as in Figure 1. These floods provided a basis for standardization of floods in regard to discharge values within the $0-1$ range, where 0 is assumed for $Q_{50 \%}$ and 1 for $Q_{\max }$. The discharge with exceedance probability $p=1 \%$ was assumed as the assigned maximum value and standardized hydrographs were converted into hydrographs for the assigned value of the maximum discharge. Reduced volume was computed for each of these hydrographs and compared with the values indicated by the dependence (Fig. 1). Selected the hydrograph, the value of reduced volume was the most approximate to the volume indicated by the relationship for $Q_{1 \%}-Q_{50 \%}$ discharge.

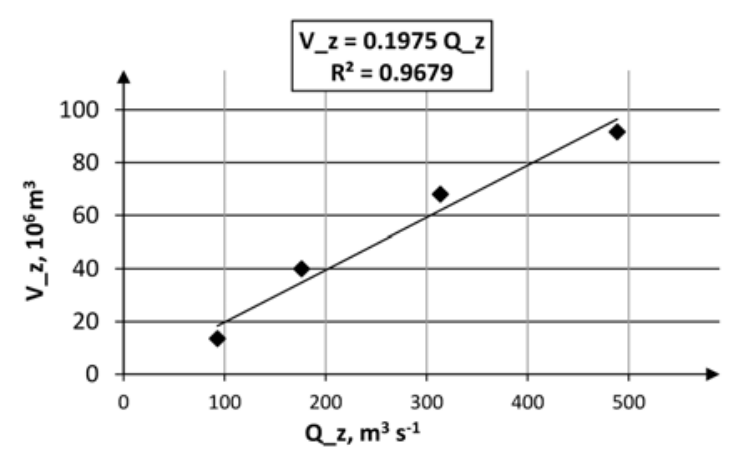

Fig. 1. Dependence of the reduced volume $V_{z} z$ on the reduced discharge $Q_{-} z$; source: own results

\section{RESULTS}

Results of computations for individual gauging stations were put in ascending order according to the catchment area, separately for the Odra and Vistula basins (Tab. 1). Nonparametric flood hydrographs calculated by means of the Cracow method and the courses of parametric floods developed on this basis using Strupczewski method were presented in Fig. 2 for selected 6 cross sections, three per ach river basin.

Subsequent figures show parametric hydrographs for four gauging stations (two per each river basin), computed for unimodal floods with the highest registered discharge value and for the typical hydrograph for its volume (Fig. 3, 4). In case when the hydrograph with the highest registered discharge is simultaneously the flood meeting the typical hydrograph criterion, the computations considered only this hydrograph (Tab. 2, 3).

The estimation of determined volumes of theoretical hydrographs was conducted twice: for the hydrograph rising limb and for the whole hydrograph. Relative deviation was determined according to the dependence (6) when the nonparametric Cracow method was used in Strupczewski method. The deviations for the floods computed for nonparametric flood hydrograph with the highest registered value and the typical hydrograph for the volume, were put in the other columns. 

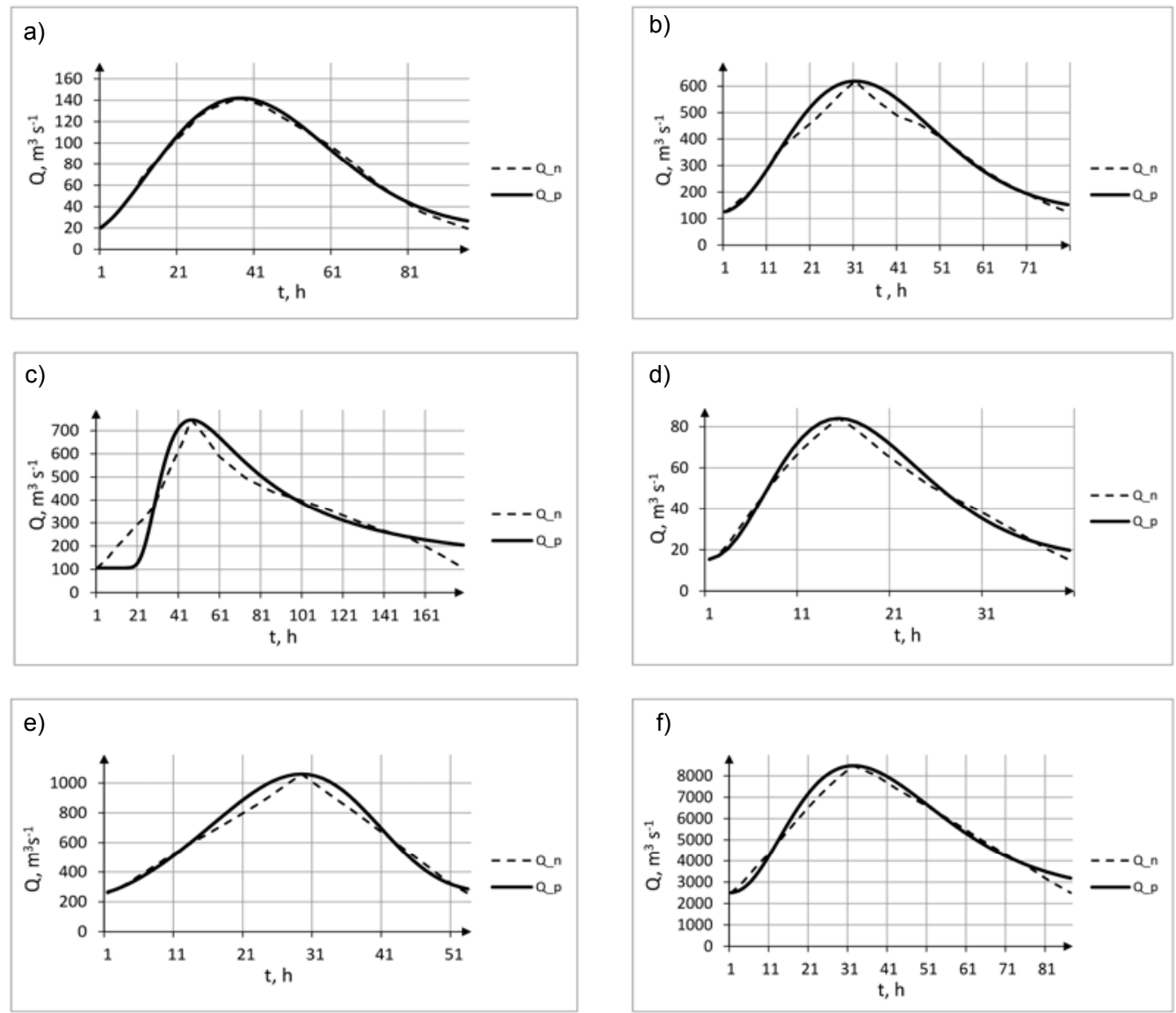

Fig. 2. Parametric waves computed according to Strupczewski method $Q_{p}$ for nonparametric flood hydrographs of the Cracow method $Q_{n}$ for the gauging stations in the Odra River basin: a) Łażany on the Strzegomka River, b) Jelenia Góra on the Bóbr River, c) Szprotawa on the Bóbr River; and in the Vistula River basin: d) Lubień on the Lubieńka River,

e) Stary Sącz on the Poprad River, f) Zawichost on the Vistula River, $t=$ time; source: own study
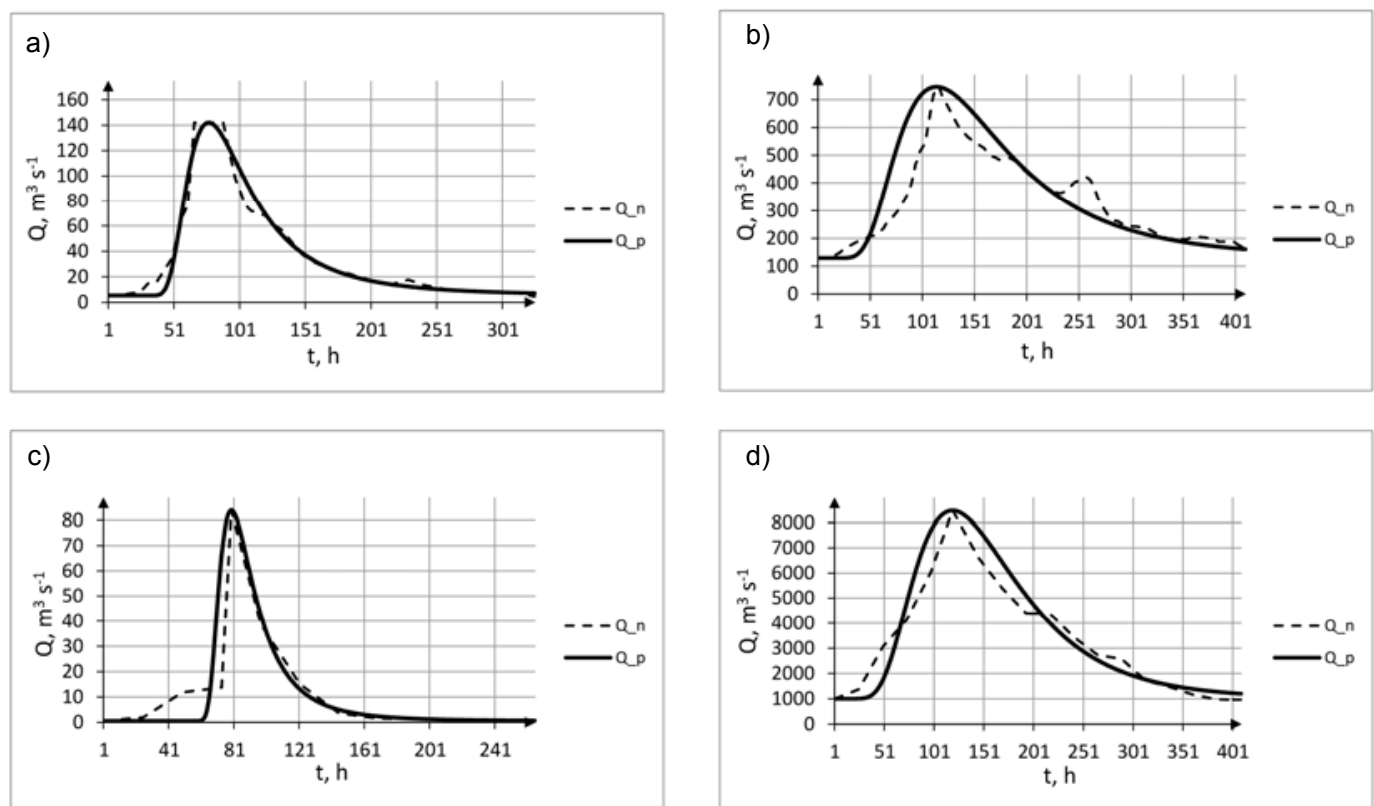

Fig. 3. Parametric flood hydrographs computed according to Strupczewski method $Q \_p$ for single flood hydrographs $Q \_n$ with the highest registered discharge for the gauging stations in the Odra River basin: a) Łażany on the Strzegomka River,

b) Szprotawa on the Bóbr River; and in the Vistula River basin: c) Lubień on the Lubieńka River, d) Zawichost on the Vistula River, $t=$ time; source: own study 

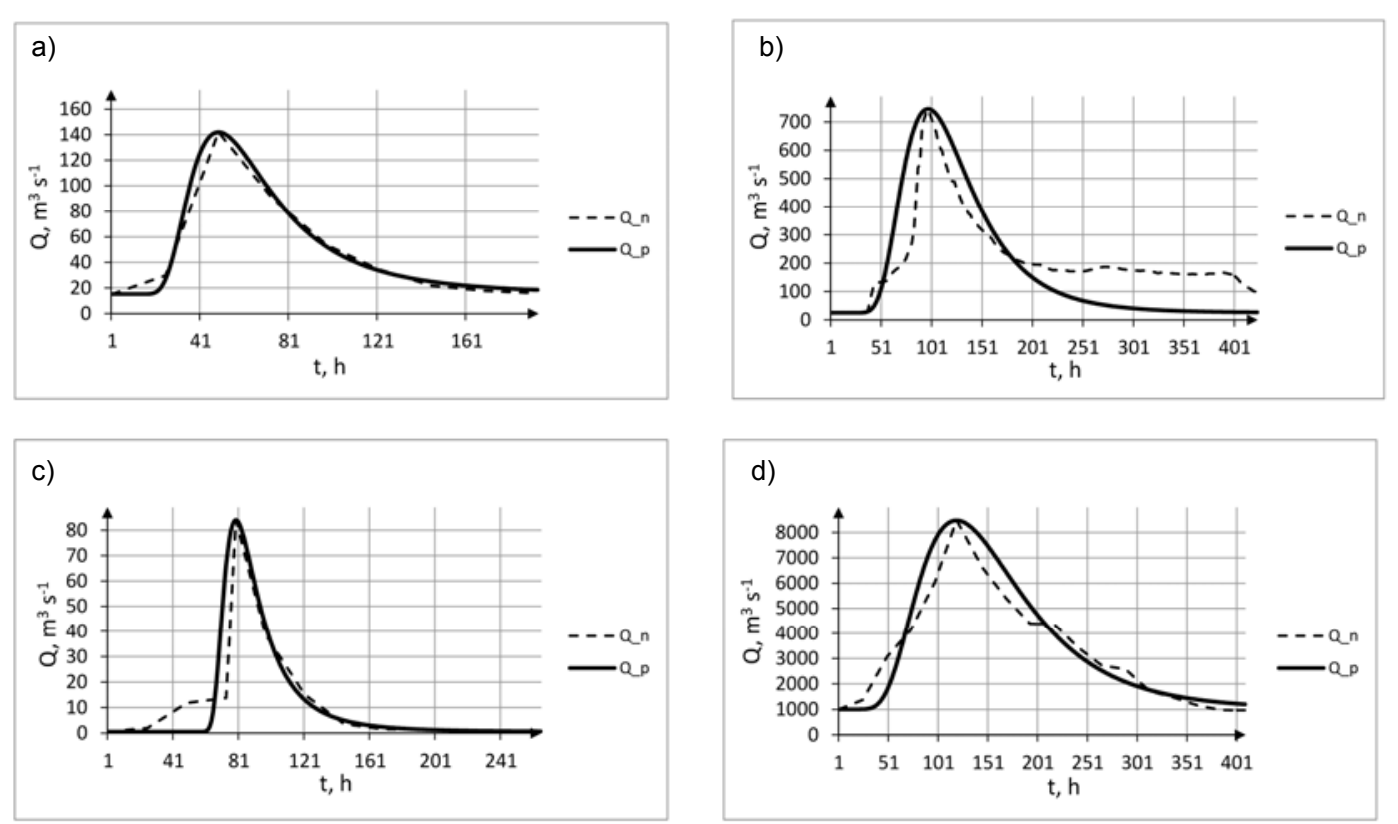

Fig. 4. Parametric flood hydrographs computed according to Strupczewski method $Q_{p}$ for single typical flood hydrographs for $Q_{n}$ volume for the gauging stations in the Odra River basin: a) Łażany on the Strzegomka River, b) Szprotawa on the Bóbr River; and in the Vistula River basin: c) Lubień on the Lubieńka River, d) Zawichost on the Vistula River; $t=$ time; source: own study

Table 2. List of deviations of relative parametric flood hydrographs determined by means of Strupczewski method regarding nonparametric floods (formula 6) in the rising limb of the hydrograph and the nonparametric flood hydrographs of the whole hydrograph computed using the Cracow method: ErV_Hw and ErV_Hc, single hydrographs with the highest registered flow ErV_Mw and ErV_Mc, single hydrographs with typical hydrographs for volume ErV_Nw and ErV-Nc

\begin{tabular}{|c|c|c|c|c|c|c|c|}
\hline \multirow{2}{*}{ No } & \multirow{2}{*}{ River - gauging station } & \multicolumn{6}{|c|}{ Relative error of computed theoretical floods volumes, $\%$} \\
\hline & & ErV_Hw & ErV_Hc & ErV_Mw & ErV_Mc & ErV_Nw & ErV_Nc \\
\hline \multicolumn{8}{|c|}{ Odra River basin } \\
\hline 1 & Nysa Kłodzka - Międzylesie & -14.3 & -2.9 & -33.2 & -8.9 & -33.2 & -8.9 \\
\hline 2 & Bystrzyca - Bystrzyca Kłodzka & 12.5 & 27.3 & -32.9 & -35.5 & -32.9 & -35.5 \\
\hline 3 & Ścinawka-Tłumaczów & 2.3 & 3.7 & -48.7 & 11.3 & -48.7 & 11.3 \\
\hline 4 & Strzegomka - Łażany & 1.4 & 1.7 & 43.6 & -4.0 & -48.4 & 4.9 \\
\hline 5 & Bóbr-Wojanów & 3.0 & 6.2 & -3.5 & 36.2 & -13.7 & 19.6 \\
\hline 6 & Bóbr - Jelenia Góra & 8.1 & 7.8 & -26.3 & 26.7 & -27.3 & -7.2 \\
\hline 7 & Nysa Kłodzka-Kłodzko & 3.4 & 0.8 & -9.4 & -2.3 & -9.4 & -2.3 \\
\hline 8 & Nysa Kłodzka - Bardo & -3.1 & 3.4 & -31.3 & -17.0 & -31.3 & -17.0 \\
\hline 9 & Bóbr-Szprotawa & -11.0 & 3.2 & 143.7 & 121.9 & 49.6 & 10.4 \\
\hline 10 & Odra-Głogów & -1.3 & 2.3 & 18.1 & 21.1 & 18.1 & 21.1 \\
\hline \multicolumn{8}{|c|}{ Vistula River basin } \\
\hline 11 & Lubieńka - Lubień & 3.6 & 4.6 & -33.5 & -34.6 & 7.1 & 29.6 \\
\hline 12 & Bystra - Kamesznica & 4.9 & 6.0 & -33.8 & 20.4 & -33.8 & 20.4 \\
\hline 13 & Koprzywianka - Koprzywnica & 7.7 & 7.5 & 0.3 & 58.1 & 0.3 & 58.1 \\
\hline 14 & Przemsza - Jeleń & 4.9 & 9.5 & 49.8 & 98.5 & 49.8 & 98.5 \\
\hline 15 & Poprad - Stary Sącz & 7.6 & 7.0 & 56.7 & 67.7 & -36.4 & 14.7 \\
\hline 16 & Nida - Brzegi & 8.6 & 5.1 & 75.3 & 81.5 & 7.5 & 29.7 \\
\hline 17 & San - Przemyśl & 2.1 & 4.0 & -1.3 & 20.7 & -1.3 & 20.7 \\
\hline 18 & Wisłoka - Mielec & 3.3 & 3.1 & -9.5 & 28.9 & -9.5 & 28.9 \\
\hline 19 & Dunajec - Żabno & 5.6 & 7.8 & 11.1 & 37.2 & 11.1 & 37.2 \\
\hline 20 & Wisła-Zawichost & 6.1 & 4.5 & 138.6 & 148.3 & 9.8 & 31.5 \\
\hline
\end{tabular}

Explanations: the $w$ symbol refers to the rising limb of the flood hydrograph, $c$ to the whole hydrograph. Source: own study.

It may be explicitly stated, that replacing the nonparametric flood hydrographs, determined using the method suggested by the author with the hydrographs computed using the Cracow method gives positive results. For a majority of the gauging stations the error, due to the volume, was lower than $10 \%$ and only in one case it exceeded $25 \%$. Much worse results were obtained when theoretical flood hydrographs were determined on the basis of a single flood, however better results were obtained for the flood hydrographs, for which a typical hydrograph was the standard hydrograph. Only in two cases the error exceeded 
Table 3. List of relative deviations according to formula (7) for theoretical flood hydrographs obtained from Strupczewski method regarding: input hydrograph determined by the Cracow method for the rising limb ErQ_hw and the whole ErQ_hc hydrograph and for real hydrograph with the highest registered ErQ_Mw and ErQ_Mc discharge, and typical hydrograph for volume ErQ_Nw and ErQ_Nc

\begin{tabular}{|c|c|c|c|c|c|c|c|}
\hline \multirow{2}{*}{ No } & \multirow{2}{*}{ River - gauging station } & \multicolumn{6}{|c|}{ Relative deviation, $\%$} \\
\hline & & ErQ_hw & ErQ_hc & ErQ_Mw & ErQ_Mc & ErQ_Nw & ErQ_Nc \\
\hline \multicolumn{8}{|c|}{ Odra River basin } \\
\hline 1 & Nysa Kłodzka - Międzylesie & 11.6 & 7.5 & 7.5 & 3.6 & 7.5 & 3.6 \\
\hline 2 & Bystrzyca - Bystrzyca Kłodzka & 7.2 & 9.5 & 7.8 & 1.7 & 7.8 & 1.7 \\
\hline 3 & Ścinawka - Tłumaczów & 11.5 & 4.1 & 17.7 & 4.9 & 17.7 & 4.9 \\
\hline 4 & Strzegomka - Łażany & 1.2 & 1.8 & 4.6 & 3.3 & 6.3 & 3.1 \\
\hline 5 & Bóbr - Wojanów & 3.0 & 4.4 & 3.7 & 8.0 & 4.6 & 7.7 \\
\hline 6 & Bóbr - Jelenia Góra & 4.1 & 3.5 & 28.5 & 7.8 & 6.6 & 4.2 \\
\hline 7 & Nysa Kłodzka - Kłodzko & 4.0 & 5.4 & 5.9 & 5.2 & 5.9 & 5.2 \\
\hline 8 & Nysa Kłodzka - Bardo & 6.9 & 5.6 & 16.3 & 5.8 & 16.3 & 5.8 \\
\hline 9 & Bóbr - Szprotawa & 10.9 & 6.1 & 13.6 & 4.9 & 12.9 & 13.2 \\
\hline 10 & Odra-Głogów & 7.2 & 4.3 & 17.2 & 6.9 & 17.2 & 6.9 \\
\hline \multicolumn{8}{|c|}{ Vistula River basin } \\
\hline 11 & Lubieńka - Lubień & 3.2 & 3.5 & 2.4 & 2.1 & 10.6 & 4.1 \\
\hline 12 & Bystra - Kamesznica & 2.9 & 3.8 & 25.0 & 4.8 & 25.0 & 4.8 \\
\hline 13 & Koprzywianka - Koprzywnica & 3.4 & 3.4 & 5.6 & 5.5 & 5.6 & 5.5 \\
\hline 14 & Przemsza - Jeleń & 2.3 & 3.6 & 5.7 & 6.4 & 5.7 & 6.4 \\
\hline 15 & Poprad - Stary Sącz & 3.7 & 3.8 & 3.0 & 3.5 & 8.6 & 4.2 \\
\hline 16 & Nida - Brzegi & 5.8 & 3.8 & 5.5 & 5.7 & 3.8 & 3.5 \\
\hline 17 & San - Przemyśl & 1.1 & 2.1 & 3.7 & 3.8 & 3.7 & 3.8 \\
\hline 180 & Wisłoka - Mielec & 1.8 & 1.9 & 3.0 & 5.6 & 3.0 & 5.6 \\
\hline 19 & Dunajec - Żabno & 3.4 & 4.5 & 3.9 & 7.7 & 3.9 & 7.7 \\
\hline 20 & Wisła-Zawichost & 4.3 & 3.0 & 9.6 & 6.2 & 10.3 & 4.2 \\
\hline
\end{tabular}

Explanations: the $w$ symbol refers to the rising limb of the flood hydrograph, $c$ to the whole hydrograph.

Source: own study.

$50 \%$. The value exceeding $100 \%$ was registered only for two hydrographs with the highest registered discharge value.

Table 3 presents the deviations from estimated value of the discharge according to the dependence (7). Value higher than $10 \%$ of the whole hydrograph was noted only in one case. It may be also stated, that irrespectively of the type of assigned input hydrograph, whether it was a nonparametric flood hydrograph or a single flood, the errors are so small that such parametric flood hydrographs may be used for engineering calculations. It should be also emphasized, that much bigger deviations occur in the rising limb of the hydrograph in comparison with the whole hydrograph and that this error not always corresponds with the error computed due to volume.

\section{CONCLUSION}

Modification of Strupczewski method, which involves the application of the Cracow method for construction of parametric flood hydrographs in place of the nonparametric method suggested by the author, has been corroborated by the conducted analyses. The weakness of nonparametric method suggested by its author is an imprecise definition of the flood, which causes that determining the rise time and the volume of hypothetical hydrographs are strongly dependent on the subjective assumption of the discharge starting the flood. Application of the Cracow method provided a possibility to eliminate these faults.
Conducted analyses allow for a statement that Strupczewski method may be used for generating parametric flood hydrographs on the basis of single real floods and not only on the basis of averaged hydrographs. However, the input hydrographs must meet the criterion of volume compliance, which is conducted on the basis of at least 4 largest observed floods. Although it is over 50 years old, Strupczewski method may in the light of these premises gain new quality and become a method commonly used, although two parameters of the hydrograph shape occur in this method. Its advantage is flexibility, i.e. a possibility to adjust to the nonparametric flood hydrographs course. Currently, the research is continued to test whether the parameters of the hydrograph shape $m$ and $n$ may support the method of transforming parametric flood hydrographs to the uncontrolled cross sections and replace the methods of such hydrographs determining on the basis of the catchment parameters using regression relationships.

\section{REFERENCES}

Apel H., Thieken A.H., Merz B., Blöschl G. 2006. A probabilistic modelling system for assessing flood risks. Natural Hazards. Vol. 38 p. 295-308.

Archer D., Foster M., FAulkner D., MaWdSLey H. 2000. The synthesis of design flood hydrographs. In: Flooding: Risks and reactions. Proceedings. CIWEM/ICE Conference. London p. 45-57.

BAPTIST M., MiCHEL C. 1990. Influence des caracteristiques hydrauliques des biefs sur la propagation des pointes de crue [Influence of hydraulic characteristics on the pro- 
pagation of flood peaks]. La Houille Blanche. No. 2 p. $141-148$.

CIEPIELOWSKI A. 1987. Statistical methods of determining typical winter and summer hydrographs for ungauged watersheds. International Symposium on Hood Frequency and Risk Analyses. Baton Rouge. Department of Civil Engineering Louisiana State University p. 117124.

CiEPIELOWSKI A. 2001. Relationships between selected elements of the flood hydrographs in rivers. Journal of Water and Land Development. No. 5 p. 89-105.

CRISS R.E., WINSTON W.E. 2008. Discharge predictions of a rainfall-driven theoretical hydrograph compared to common models and observed data. Water Resources Research. Vol. 44. Iss. 10. DOI: 10.1029/2007WR 006415.

Downer C.W., Johnson B.E., Ogden F.L., Meselhe E.A. 2000. Advances in physically based hydrologic modeling with CASC2D. In: Watershed Management and Operations Management. Proceedings. Vol. 105 p. 1-10. DOI: $10.1061 / 40499(2000) 48$.

GĄDEK W., BODZIONY M. 2015. The hydrological model and formula for determining the hypothetical flood wave volume in non-gauged basin. Meteorology Hydrology and Water Management. Vol. 3. No. 1 p. 3-10.

GĄDEK W., Środula A. 2014. The evaluation of the design flood hydrographs determined with the Hydroproject method in the gauged catchments. Infrastruktura i Ekologia Terenów Wiejskich. Nr IV/3 p. 1355-1366.

GĄDEK W., TOKARCZYK T. 2015. Determining hypothetical floods in the Odra basin by means of the Cracow method and by volume formula. Infrastruktura i Ekologia Terenów Wiejskich. Nr IV/4 p. 1507-1519.

HATTERMANN F.F., KunDZEWICZ Z.W. (ed.) 2010. Water framework directive: Model supported implementation. A Water Manager's Guide. London. IWA Publishing. ISBN 9781843392736 pp. 268.

Hayashi T., Nagamine Y., Nishida A. 1986. A vibration model to describe the lactation curve of a dairy cow. Japanese Journal of Zootechnical Science. Vol. 57. No. 6 p. 471-478.

KRIŠČIUKAitienĖ I., BALEŽEntis T., GALNAitytė A., NAMIOTKO V. 2015. A methodology for flood risk appraisal in Lithuania. Journal of Water and Land Development. No. 25 p. 13-22.

MCENROE B.M. 1992. Sizing stormwater detention reservoirs to reduce peak flow. In: Hydraulic engineering: saving a threatened resource - in search of solutions.
Conference Proceeding Paper. Reston. VA. ASCE. p. 719-724.

MioduszewSKI W. 2012. Small water reservoirs - their function and construction. Journal of Water and Land Development. No. 17 p. 45-52.

MioduszeWSKI W. 2014. Small (natural) water retention in rural areas. Journal of Water and Land Development. No. 20 p. 19-29.

O'CONNOR K., Goswami M., Faulkner D. 2014. Flood studies update. Technical Research Report. Vol. 3. Hydrograph Analysis. Office of Public Works pp. 186.

OZGA-ZIELIŃSKA M., GĄDEK W., KSIĄŻYŃSKi K., NACHLIK E., SZCZEPANEK R. 2002. Mathematical model of rainfall-runoff transformation - WISTOO. In: Mathematical models of large watershed hydrology. Ed. V.P. Singh, D.K. Frevert. Water Resources Publications, LLC, Littleton, Colorado p. 811-860.

Pietrusiewicz I., Cupak A., Walęga A., Michalec B. 2014. The use of NRCS synthetic unit hydrograph and Wackermann conceptual model in the simulation of a flood wave in an uncontrolled catchment. Journal of Water and Land Development. No. 23 p. 53-59.

STRUPCZEWSKI W. 1964. Równanie fali powodziowej [Equation of flood crest]. Wiadomości Służby Hydrologicznej i Meteorologicznej. Z. 2(57) p. 35-58

TOKARCZYK T., SZALIŃSKA W. 2013. The operational drought hazard assessment scheme - performance and preliminary results. Archives of Environmental Protection. Vol. 39. No. 3 p. 61-77.

VRIJLING J.K., VAN Hengel W., Houben R.J. 1998. Acceptable risk as a basis for design. Reliability Engineering and System Saferty. Vol. 59 p. 141-150.

WAŁĘGA A. 2013. Application of HEC-HMS programme for the reconstruction of a flood event in an uncontrolled basin. Journal of Water and Land Development. No. 18 p. 13-20.

WyPyCh A., Ustrnul Z., HeneK E. 2014. Meteorological hazards - visualization system for national protection against extreme hazards for Poland. Meteorology Hydrology and Water Management. Vol. 2. No. 1 p. 3742.

WMO 2008. Urban flood risk management. A tool for integrated flood management [online]. [Access 05.08.2015]. Available at: http://www.apfm.info/publications/tools/ Tool_06_Urban_Flood_Risk_Management.pdf

ZEVEnBERgEN C., CASHMAN A., EvelPidOU N., PASChE E., GARVIN S., ASHLEY R. 2011. Urban flood management. Boca Raton. CRC Press. ISBN 0415559448340 pp. 370.

\section{Wieslaw GĄDEK, Tamara TOKARCZYK, Arkadiusz ŚRODULA}

\section{Ocena fal parametrycznych wyznaczonych metodą Strupczewskiego w dorzeczu Wisły i Odry}

\section{STRESZCZENIE}

Do wyznaczania fal teoretycznych stosowane są różne metody ich konstruowania w zależności od potrzeb rozwiązywanego zadania lub zakresu projektu. Należy pamiętać, że te metody różnią się głównie zasadą uśredniania przebiegu fali, które może odbywać się z uwagi na przepływ bądź z uwagi na czas. Fale te można podzielić na nieparametryczne, które wyznaczane są na podstawie zarejestrowanych wezbrań powodziowych, i parametryczne, do których wykorzystuje się matematyczny opis przebiegu wezbrania. Ważną rolą w rozwiązaniach parametrycznych odgrywa metoda nieparametryczna, za pomocą której określa się przebieg wezbrania wejścio- 
wego wykorzystywanego w obliczeniach. Jedną z metod analitycznego opisu fali wezbraniowej jest opracowana ponad 50 lat temu metoda Strupczewskiego. W metodzie tej, w odróżnieniu od innych metod analitycznych, wykorzystuje się dwa parametry odpowiedzialne za kształt fali oraz parametr określający przepływ bazowy, czyli przepływ powyżej którego obliczane są wartości hydrogramu. Do opisu funkcyjnego wykorzystuje się rozkład gęstości Pearsona typu III.

W pracy przeprowadzono ocenę wezbrań parametrycznych wyznaczonych metodą Strupczewskiego w przypadku, kiedy falę nieparametryczną zaproponowaną przez autora metody zastąpiono falą nieparametryczną, obliczoną tzw. metodą krakowską. Przeprowadzono także test, w którym dokonano oceny obliczonych wezbrań dla pojedynczych rzeczywistych hydrogramów o największym zarejestrowanym przepływie i dla hydrogramów tzw. typowych z uwagi na objętość.

Analizy porównawcze przeprowadzono dla 20 stacji wodowskazowych usytuowanych na obszarze zlewni górnej Wisły i na środkowej Odrze. Jako zlewnie testowe wybrano zlewnie o różnych powierzchniach i różnym charakterze: górskim, pogórskim, wyżynnym i nizinnym. Przeprowadzona ocena wykazała, że fale hipotetyczne wyznaczone metodą krakowską mogą być stosowane w metodzie Strupczeskiego jako nieparametryczny hydrogram wejściowy. Również rzeczywiste hydrogramy spełniające kryterium fali typowej z uwagi na objętość mogą być podstawą do wyznaczania wezbrania parametrycznego. Fale o najwyższych zarejestrowanych wartościach w niektórych przypadkach nie dają zadowalających przebiegów teoretycznych.

Słowa kluczowe: hydrogram analityczny, hydrogram nieparametryczny, hydrogram parametryczny, metoda Strupczewskiego, metoda krakowska, hydrogram typowy 